Article

\title{
Corporate Taxation and Firm-Specific Determinants of Capital Structure: Evidence from the UK and US Multinational Firms
}

\author{
Sarmad Ali ${ }^{1} \mathbb{D}$, Adalberto Rangone ${ }^{1, * \mathbb{D}}$ and Muhammad Farooq ${ }^{2} \mathbb{D}$ \\ 1 Department of Management and Business Administration, G.d'Annunzio University of Chieti-Pescara, \\ Viale Pindaro, 42, 65127 Pescara, Italy; sarmad.ali@unich.it \\ 2 Institute of Business Management and Administrative Sciences, University of Bahawalpur, Bahawalpur 63100, \\ Pakistan; alihussnain155@yahoo.com \\ * Correspondence: adalberto.rangone@unich.it
}

check for updates

Citation: Ali, Sarmad, Adalberto Rangone, and Muhammad Farooq. 2022. Corporate Taxation and Firm-Specific Determinants of Capital Structure: Evidence from the UK and US Multinational Firms. Journal of Risk and Financial Management 15: 55. https:// doi.org/10.3390/jrfm15020055

Academic Editor: Khaled Hussainey

Received: 29 November 2021

Accepted: 18 January 2022

Published: 25 January 2022

Publisher's Note: MDPI stays neutral with regard to jurisdictional claims in published maps and institutional affiliations.

Copyright: (c) 2022 by the authors. Licensee MDPI, Basel, Switzerland. This article is an open access article distributed under the terms and conditions of the Creative Commons Attribution (CC BY) license (https:/ / creativecommons.org/licenses/by/ $4.0 /)$.

\begin{abstract}
This paper aims to examine whether effective tax rate and firm-specific factors (such as firm size, growth opportunities, tangibility, risk, profitability, non-debt tax shields and liquidity) impact the capital structure of multinational firms in the energy sector. We employ regression models consisting of OLS, fixed effect and random effect to test balanced panel dataset of multinational firms based in the UK and USA over the period 2011-2019. We show a positive and significant effect of tangibility, risk, profitability and non-debt tax shields on long-term and total debt measures of capital structure. In the case of short-term debt, however, we reveal that it is significantly negatively related to tangibility, non-debt tax shields and liquidity, and positively associated with firm risk. Moreover, we report that the effective tax rate and firm size are insignificantly negatively related to the leverage choices of multinational firms, and liquidity has a significant inverse relationship with long-term debt and total debt. This study reveals mixed support for the prevailing capital structure theories and evidence that multinational firms are unequivocally responsive to the capital structure. The results significantly contribute to evaluating multinational firms in the energy sector and show how managers can achieve an optimal level of capital structure.
\end{abstract}

Keywords: capital structure; effective tax rate; firm-specific factors; multinational firms

\section{Introduction}

The selection of capital structure determinants has been subjected to controversy over the decades. A firm's capital structure is influenced by changes in macroeconomic and firm-specific factors. A substantial body of literature has investigated the various theories of capital structure and the implications of macroeconomics and firm-level factors. Since the mid-twentieth century, various theories of capital structure have been developed that play an extensive role in explaining the determinants of capital structure. In the corporate finance literature, the pioneer theory of capital structure was presented by Modigliani and Miller $(1958,1963)$, extended by trade-off theory (Kraus and Litzenberger 1973), agency cost theory (Jensen and Meckling 1976), the pecking order theory (Myers 1984) and the market timing theory (Graham and Harvey 2001). Simultaneously, several empirical studies on the impact of the firm's level factors, such as firm size, profitability, growth potential, risk and tangibility on capital structure have been studied (Rajan and Zingales 1995; Titman and Wessels 1988; Booth et al. 2001; Chakraborty 2010). Although the Modigliani and Miller (M\&M) theory considered the benefits of debt tax incentives, the arguments used to justify this notion of maximizing debt ratio to capture tax benefit incentives were inappropriate because they ignored other factors, such as asymmetric information, bankruptcy costs and agency problems, which led to the development of modern capital structure theories. Myers (1984) named this phenomenon "the capital structure puzzle". A recent work by Heider and Ljungqvist (2015) and Barclay et al. (2013) showed a significant influence of corporate taxation on the capital structure, since the trade-off theory identified this relationship as 
a cost and benefit analysis of borrowings. This theory postulates that a company should have high leverage in a country with a high corporate tax rate (such as the US with a 35\% statutory federal rate, one of the highest corporate tax rates among all OECD countries).

Myers (2001) argues that the theories of capital structure have certain conditions, propositions and assumptions, hence providing an incomplete picture while investigating the determinants of capital structure. The pecking order theory neglects the importance of the target level of capital structure as proposed by the trade-off theory, as it establishes a hierarchy in the selection of financing choices that begin with an internal source of financing, such as retained earnings, followed by borrowing and, finally, equity as an external source. Ross (2007) argues that the pecking order is more suitable for short-term strategies, whereas the trade-off theory supports long-term financial strategies. Extant studies mostly revealed a significant relationship between corporate taxation and capital structure (Faccio and $\mathrm{Xu}$ 2015; Fan et al. 2012). A substantial number of studies examined the role of debt bias in the case of multinational firms by examining country-specific factors (Graham et al. 1998; Gordon and Lee 2007; Huizinga et al. 2008; Mills and Newberry 2004). The studies of (Booth et al. 2001; Giannetti 2003; De Jong et al. 2008) suggest that institutional differences across countries are important parameters that have a solid potential to tempt substantial changes in capital structure choices. The divergence of results in previous studies is observed due to institutional dissimilarities among countries that are attributed to taxation, stock markets development, creditor protection and legal systems. The cost and benefits of debt financing are likely to vary based on the institutional environment (Rajan and Zingales 1995; Demirgüç-Kunt and Maksimovic 1996; La Porta et al. 1997). Long-term debt is more associated with a well-organized bankruptcy environment, while short-term debt relies on an efficient legal and information symmetric environment. The regulatory environment plays a pivotal role in the decision of obtaining both long- and short-term debt (Mc Namara et al. 2017).

Multinational firms borrow and operate in several countries. Their aggregate borrowing depends on the tax rates in those countries (Huizinga et al. 2008; Desai et al. 2004; Arena and Roper 2010). A better trade-off between debt and equity financing might reduce non-financial companies' leverage through tax policy reforms. The firms' characteristics considerably impact the sensitivity of company leverage to the effective tax rate (Dallari et al. 2020). In an international context, the taxation cost of debt and equity financing are determined by the combined tax systems of the multinational firm's subsidiary and parent countries. The higher debt incentives in one country encourage debt shifting in that country. However, they discourage debt financing in another country at the same time to keep the overall indebtedness of a multinational under control (Huizinga et al. 2008). The ideal debt-to-assets ratio at each of the multinational's locations is influenced favorably by both the national tax rate and the difference between the national tax rate and the tax rate in other countries. Effective tax rates are what matters here, since they account for any double taxation and double taxation relief that may exist. Because of the different tax rates in different countries, shifting debt becomes more appealing. Empirical studies show that several firms' characteristics of firm size, growth opportunities, risk and profitability have a pronounced impact on capital structure (Bhaduri 2002; Homaifar et al. 1994; Titman and Wessels 1988). It is also well evident in the previous studies that industry-specific characteristics are essential in determining a firm's capital structure. (MacKay and Phillips 2005). When making financial decisions, the firm's characteristics are essential. It is, therefore, worthwhile to investigate the impact of corporate taxation and firms' characteristics in a specific industry. However, only a few studies have explored the impact of corporate taxation and firm-level factors on the capital structure of multinational firms in a distinct institutional context (Baker and Riddick 2013). The public limited firms are widespread in the UK and US, and hostile takeovers are common due to agency problems (McClure et al. 1999; Rajan and Zingales 1995).

Based on the previous literature on capital structure, we intend to examine the effects of corporate taxation and firms' characteristics on the capital structure of multinational 
firms in the energy sector. We contribute to the existing debate on the effects of corporate taxation and firm-specific characteristics on the capital structure in several ways. First, we attempt to focus on the sample of listed multinational firms in market-based economies where the stock markets are large and more active relative to their banking systems, with strong shareholder's rights, better legal system and accounting regulations (DemirgüçKunt and Maksimovic 1996), such as the UK and US. To the best of our knowledge, this distinguishes our work from extant studies that are reported in the context of domestic firms solely from a single country. Secondly, we represent a distinctive approach considering one specific industry, such as the energy sector, since this is a highly regulated sector due to substantial use of external financing, and it secures a significant amount of debt financing, incurs high upfront capital expenditure, operational and indebtedness costs due to high tangibility and manufacturing aspects of business activities. Finally, our work extends the choice of theoretical determinants of capital structure by investigating several explanatory variables to represent their effect on the capital structure.

Energy sector financing requires high upfront capital and debt with long-term maturity (Dayanandan and Donker 2011). Energy-related projects are more vulnerable to high risks, which have a substantial influence on their financing (Thillairajan and Behera 2016). Since this sector involves heavy manufacturing, it requires a greater level of leverage to finance major capital expenditures than the services sector, where there is a reduced usage of fixed assets (Gill et al. 2009; Damodaran 2012). Thus, insufficient funding, excessive operating and debt costs may stifle energy industry expansion (Masini and Menichetti 2012; Truly and Moore 2016). Furthermore, the oil and gas companies pay a portion of corporate income tax and other payments, such as royalties, rental fees and special petroleum profit taxes as part of a concession, and may be eligible for direct or indirect tax breaks that vary from year to year, as well as from country to country (EY 2019, Global Oil and Gas Tax Guide). The energy sector has a high amount of capital expenditures due to enormous production and exploration activity. This industry's debt finance, which includes company bonds and bank loans, provides significant funding (Brogan 2014).

Companies in the energy sector are more indebted than other manufacturing firms because they invest more in fixed assets than firms in the services sector. Further, on average, the continual energy price shocks are higher than for firms in other UK industries (Rashid 2013). Harris and Raviv (1991) stated that the energy sector's substantial tangible assets boost debt levels due to easy loan availability. In the given context, the empirical work to target the energy sector would be helpful to investigate how corporate taxation and firm-specific characteristics impact the capital structure of multinational firms. The focus on this sector is essential because investment increases the need for external financing to help firms grow, yet the costs of debt may outweigh the benefits (Cariola et al. 2020). The primary goal of this study is to conduct a critical analysis of the impacts of corporate taxes and firm-level features on multinational firms' capital structures in the energy industry to give essential insights for making sustainable financial decisions about capital structure management. We examine empirically how corporate effective tax rate and firm-level factors affect the capital structure of multinational firms.

The rest of the paper is laid out as follows. First, in Section 2, we review the literature to develop our research hypothesis. Next, the methodology is presented in Section 3. Then, empirical results and robustness checks are reported in Section 4. Finally, Section 5 concludes the paper.

\section{Literature Review}

Numerous empirical studies have been conducted to examine the impact of corporate taxation on capital structure. The debt-related tax advantages differ by taxation system, and there is a substantial positive association between average leverage and tax shield indices in OECD nations (Castillo et al. 2017). The determinants of capital structure are country specific and may generate different results in different institutional settings (Delcoure 2007). The companies that operate in an imputation tax system hold significantly less 
short-term and long-term debt than companies within the classical taxation system. While the majority of empirical research on capital structures is conducted in the US, it is argued that focusing on a single country may obscure the impact of the diversity of financial systems and economic traditions across countries on the capital structure, owing to distinct taxation systems, agency codes, bankruptcy laws, as well as industry-level characteristics (Akhtar 2017).

According to Colombo and Caldeira (2018), taxation is a first-order predictor of business financial decisions. Due to the interconnection of various financial instruments, the debt and equity tax shields operate as alternative financial instruments that firms use to adjust their strategies. Tax changes rarely influence a single industry, firm or individual, but they frequently affect all economic stakeholders, from ownership structure to institutional environment. Bartholdy and Mateus (2011) investigated the impact of corporate taxation on capital structure and found a statistically significant relationship between debt tax benefits and capital structure. Da Fonseca et al. (2020) used tax proxies to evaluate 259 non-financial Brazilian firms from 2008 to 2018, establishing a positive relationship between debt tax incentives and corporate leverage by treating tax benefits as a driving force of financial leverage. Clemente-Almendros and Sogorb-Mira (2017) examined the debt tax benefits associated with deducting interest on taxable income. Interest expenses incurred by US corporates are tax deductible, as they are in the UK. While the interest payments are deductible at the corporate level and serve as an interest tax shield, the equity contribution does not result in tax distortion. As a result, debt is more attractive than equity, by comparison (Rünger and Haring 2019). On the contrary, the personal income tax may fully or partly offset the benefits of corporate income tax (Miller 1977). Faulkender and Smith (2016) in their empirical study showed that firms prefer high leverage in countries with a high corporate tax rate on taxable revenue. Auerbach et al. (2017) discussed the role of cash-flow tax that may restore the neutrality between equity and debt finance to overcome debt bias, as well as how a tax on borrowing could counterbalance preferential taxation treatments in the US.

Heider and Ljungqvist (2015) find that taxation has a direct impact on financial structure. Companies prefer equity over debt when the US firms' tax rate rises. However, low tax rates do not reduce the level of leverage. Global fluctuations in personal and corporate tax rates imply taxes are a first-order determinant of capital structure (Faccio and Xu 2015). Moreover, the double tax treaty plays an imperative role to avoid double taxation of multinational firms. Indeed, the OECD model treaty, which highlights recommended practice, provides countries with an option for avoiding double taxation: an exemption or a foreign tax credit (OECD 1997). The foreign tax credit offsets domestic taxes on foreign-source income on a one-to-one basis, with international taxes already paid. The foreign tax credit might be indirect in that it applies to both the dividend withholding tax and the corporate income tax of the underlying subsidiary country. In addition, the foreign tax credit is direct and solely applies to withholding tax. In any case, tax credits are often limited to avoid a negative domestic tax burden on foreign source income. In terms of double taxation relief, the parent country has three primary options: (i) an exemption, (ii) a foreign tax credit or (iii) a deduction. In most countries, foreign-source interest flows are viewed as benefiting from a foreign tax credit, particularly when interest payments originate from treaty partners (Huizinga et al. 2008). Devereux et al. (2018) found a strong tax effect on leverage among domestic and multinational companies in the UK using a dynamic capital structure model. Compared to domestic firms, the multinational firms' response to changes in tax rates is quite different because they allocate their debt internally, according to different tax jurisdictions, to lower their tax liabilities (Desai et al. 2004). Furthermore, they discovered that multinationals' external leverage is less sensitive to changes in tax benefits than domestic enterprises and that multinationals alter their external leverage more quickly than domestic firms. Macnamara (2019) used a detailed financing dynamic model, using the Compustat database to examine trends between 1980 and 2012 and finding that external equity costs have fallen significantly, while company leverage ratios have fallen due to 
reduced debt tax benefits. Wenhong et al. (2015) stated that income tax rates significantly impacted a firm's capital structure listed in China. They further observed that the listed companies have lower financial leverage when the income tax rate drops. Hence, they reported a positive association between corporate taxation and capital structure. Longstaff and Strebulaev (2014) investigated the relationship between corporate tax charges and leverage, using the US IRS database consisting of filled corporate income tax returns, and reported a significant positive relationship between corporate tax rate and capital structure. The preceding findings lead to the formulation of the following hypothesis:

\section{Hypothesis 1 (H1). There is a positive relationship between corporate taxation and leverage.}

In contrast to large firms, small and medium-sized enterprises (SMEs) generally do not easily access capital markets. The firm size is an essential determinant of capital structure as a firm-specific factor. SMEs differ from large firms because they have fewer diverse financing sources and are typically bank based. They are less inclined toward tax planning and thus get less debt tax benefits than large listed firms (Kuntchev et al. 2014). McConnell and Pettit (1984) argued that small firms tend to be less profitable with fewer tax benefits based on deductible interest payments than larger firms. Moreover, small firms largely depend on short-term debt, whereas large firms' financing mainly comes from long-term debt (Allen et al. 2006). Frank and Goyal (2009) find a positive relationship between firm size and leverage, since large firms are more diversified and thus less risky, in line with the trade-off theory. Conversely, Lemmon et al. (2008) and Hanousek and Shamshur (2011) analyze a negative relationship between firm size and leverage. This is consistent with the trade-off theory, which predicts the significant and positive association between firm size and leverage due to the fact that large firms are characterized as more diverse, less risky and less likely to go bankrupt (Acaravci 2015). Moreover, Rajan and Zingales (1995) argue that larger firms are more diverse and fail less frequently, firm size measured in terms of natural logarithm of sales and total assets could reduce the likelihood of bankruptcy. If this is the case, size should have a positive impact on the supply of debt. Nevertheless, large firms may have lower agency costs in association with the asset substitution and underinvestment problems. Therefore, large firms have higher debt ratio as compared to small firms because their chances of liquidation are lower at the time of financial distress (Chung 1993; Ozkan 1996). In the view of pecking order theory, Harris and Raviv (1991) suggested a positive relationship, since large firms (with more tangible assets) may give lenders more information, resulting in improved possibilities to satisfy the demands of debt providers. Jaworski and Czerwonka (2021) investigated the capital structure determinants of companies in the energy sector in 25 European Union (EU) countries and reported strong evidence for the positive association between firm size and corporate debt. Based on the above arguments, the hypothesis is as follows:

Hypothesis $2 \mathbf{( H 2 ) . ~ T h e r e ~ i s ~ a ~ p o s i t i v e ~ r e l a t i o n s h i p ~ b e t w e e n ~ f i r m ~ s i z e ~ a n d ~ l e v e r a g e . ~}$

Harris and Raviv (1991) first empirically investigated the relationship between tangibility and leverage in the US, and the study was later extended to G7 economies by Rajan and Zingales (1995). Asset tangibility is a key driver that significantly affects the capital structure of manufacturing sectors. The tangible assets' compositions in these sectors have higher collateral value, hence revealing a positive and significant impact on the leverage (Booth et al. 2001; Zou and Xiao 2006; Chen 2004). According to the agency theory and the trade-off theory, there is a positive relationship between tangible assets and leverage, since the financial markets are willing to finance firms with high tangibility, as these assets have high collateral value, and repossess them in case of bankruptcy. These assets could also be used to secure long-term debt financing, in line with the findings of (Booth et al. 2001; Lemmon et al. 2008; Frank and Goyal 2009; Céspedes et al. 2010; Terhaag 2015). The following hypothesis is formulated: 
Hypothesis 3 (H3). There is a positive relationship between asset tangibility and leverage.

The trade-off theory explains a negative association between firms' risk and target leverage (Castanias 1983; Bradley et al. 1984), as opposed to the pecking order theory that postulates a positive impact of risk on leverage (Myers 1977). Castanias (1983) documents the negative relationship using the tax-shelter bankruptcy model. Toy et al. (1974) report a significant positive effect of risk on a firm's leverage in the U.S, Norway and Japan. Kale et al. (1991) find that business risk declines the level of debt at an early stage and show a roughly U-shaped relationship between business risk and optimal debt leverage. When debt exceeds a particular limit, leverage falls initially and then increases, resulting in high business risk. However, some studies (Lemmon et al. 2008; Baum et al. 2009) revealed a negative relationship between risk and leverage. Drobetz and Fix (2003) reported an insignificant and negative connection between volatility and leverage. Thus, they are consistent with the trade-off theory, which suggests that a high volatility rate in cash flows increases the likelihood of bankruptcy. The hypothesis can be drawn as follows:

\section{Hypothesis 4 (H4). There is a negative relationship between risk and leverage.}

Ali et al. (2012) used regression analysis to investigate the impact of profitability on capital structure in the petroleum sector and reported a significant positive relationship between them. Salawu (2007), on the other hand, conducted an empirical analysis of the capital structure of Nigerian companies and demonstrated that leverage is insignificantly negatively related to profitability. In contrast with the pecking order theory, the trade-off theory postulates a significant positive relationship between profitability and leverage because companies are more likely to be leveraged and benefit from corporate tax shields (Frank and Goyal 2003; Antoniou et al. 2008; Wu and Yue 2009). However, previous empirical studies found a negative relationship between profitability and leverage as a result of asymmetric information influencing firms' financing decisions (Myers and Majluf 1984; Rajan and Zingales 1995; Booth et al. 2001; Handoo and Sharma 2014; Fama and French 2002). The hypothesis is as follows:

\section{Hypothesis 5 (H5). There is a negative relationship between profitability and leverage.}

Previous empirical studies found a significant negative relationship between non-debt tax shield and leverage. This is because non-debt tax shields are generally regarded as an alternative to the tax deductibility provided by debt financing (Kim et al. 2006; Frank and Goyal 2009; Rajagopal 2011). Bradley et al. (1984) and Mukherjee and Mahakud (2010) argued that large companies own a large volume of fixed assets and can afford higher depreciation and amortization costs, encouraging them to use more debt. Hence, they asserted a positive association between non-debt tax shields and leverage. The tax shields consist of certain financial tools, such as amortization, depreciation, research and development expenditure, carry-forwarded tax loss credits and advertising expenses that reduce the annual earnings before interest and tax (EBIT) and the tax incentives of debt financing. Therefore, the companies are less likely to obtain debt financing due to higher depreciation and amortization costs, leading to lower taxable income. Consequently, the negative association between non-debt tax shields and leverage is expected.

Hypothesis 6 (H6). There is a negative relationship between non-debt tax shields and leverage.

The highly liquid firms are more likely to have substantial internal funds that lower their need to secure more debt financing. In line with the pecking order theory, companies with higher liquidity ratios tend to rely on internal funds to finance their projects. Therefore, previous literature stated a negative relationship between liquidity and leverage (Sheikh and Wang 2011; Eriotis et al. 2007; Chaklader and Chawla 2016). On the contrary, the tradeoff theory anticipates a positive relationship, indicating that firms with higher liquid assets 
facilitate the process of debt servicing by providing more collateral assets and security to the lenders. Moreover, a higher current ratio as a measure of liquidity is attributed to the fact that firms are better positioned to manage short- and long-term financial constraints, which persuades them to obtain debt financing (Al-Najjar and Taylor 2008; Ramli et al. 2019).

Hypothesis 7 (H7). There is a negative relationship between liquidity and leverage.

\section{Methodology}

\subsection{Research Design and Variable Formation}

We attempt to use panel data consisting of cross-sectional and time series analysis to employ ordinary least square (OLS), fixed-effect, as well as random-effect models, to understand the impact of changes in effective tax rate and firm-specific determinants on the capital structure of multinational firms in the energy sector. The analysis of panel data is more robust than cross-section or time series, as it is more appropriate to capture the individual cross-section differences (Chaklader and Chawla 2016). An OLS regression reduces errors between observed and estimated points. Due to measurement error, the fixed-effect model may produce more biased results than OLS. However, heterogeneity and individual firm effects may affect OLS assumptions. The fixed-effect model accounts for each firm's individuality or cross-section unit through each firm at intercept, while assuming the slope coefficients remain constant across firms. The random-effect model, on the other hand, assumes uncorrelated units and estimates uncorrelated coefficients. We also run the Hausman test to see which model best explains fixed or random effect estimation. The following three estimations assess whether changes in effective tax rates and firm-specific characteristics affect a capital structure:

$$
\begin{aligned}
& \mathrm{CS}_{\mathrm{it}}=\alpha+\beta 1(\text { ETR })_{i t}+\beta 2(\text { SIZE })_{i t}+\beta 3(\text { TANGIBILITY })_{i t}+\beta 4(\text { RISK })_{i t}+ \\
& \beta 5(\text { PROFITABILITY })_{i t}+\beta 5(\text { NTDS })_{i t}+\beta 5(\text { LIQUIDITY })_{i t}+\varepsilon_{i t} \\
& C S_{i t}=\alpha+\beta 1(\text { ETR })_{i t}+\beta 2(\text { SIZE })_{i t}+\beta 3(\text { TANGIBILITY })_{i t}+\beta 4(\text { RISK })_{i t}+ \\
& \beta 5(\text { PROFITABILITY })_{i t}+\beta 5(\text { NTDS })_{i t}+\beta 5(\text { LIQUIDITY })_{i t}+\mu_{i t}+\varepsilon_{i t} \\
& C S_{i t}=\alpha+\beta 1(\text { ETR })_{i t}+\beta 2(\text { SIZE })_{i t}+\beta 3(\text { TANGIBILITY })_{i t}+\beta 4(\text { RISK })_{i t}+ \\
& \beta 5(\text { PROFITABILITY })_{i t}+\beta 5(\text { NTDS })_{i t}+\beta 5(\text { LIQUIDITY })_{i t}+\mu_{i t}
\end{aligned}
$$

The $\mathrm{CS}_{\text {it }}$ is the debt-to-equity ratio of a company, i refers to the individual firms in time t. Corporate taxation is expressed as ETR, whereas the firm's level variables are firm size, growth opportunities, tangibility, growth, risk and profitability. The firm's fixed effects are signified as $\mu_{i t}$ and $\varepsilon_{i t}$, donated as disturbance term. The choice of leverage measurement is critical because past studies have used different definitions of leverage based on book or market value (Titman and Wessels 1988). In this research, the book value of leverage is used as a proxy of capital structure. The dependent variable is the book value of the short-term, long-term and total debt divided by the book value of total assets. The total debt excludes non-interest-bearing liabilities, such as accrued liabilities, deferred tax and accounts payable in line with (Moradi and Paulet 2019). The corporate tax is measured as per effective tax rate as the ratio of tax paid reported on companies' financial statements, and firm-level characteristics are considered independent variables that have the propensity to affect the capital structure of a multinational in the energy sector. The variable measurements are reported in Table 1. 
Table 1. Independent and dependent variable formulation.

\begin{tabular}{|c|c|c|}
\hline Independent Variables & Formulation & Empirical Evidence \\
\hline Effective tax rate & $\begin{array}{l}\text { Ratio of corporate tax paid to } \\
\text { taxable income }\end{array}$ & \multirow{2}{*}{$\begin{array}{l}\text { Devereux et al. (2018), } \\
\text { Longstaff and Strebulaev (2014). } \\
\text { Rajan and Zingales (1995), } \\
\text { Karadeniz et al. (2011). }\end{array}$} \\
\hline Firm size & Total assets natural logarithm & \\
\hline Asset tangibility & Fixed assets divided by total assets & Rajan and Zingales (1995). \\
\hline Risk & $\begin{array}{l}\text { co-efficient of variation in profit } \\
\text { before interest and tax }\end{array}$ & $\begin{array}{l}\text { Huang and Ritter (2009), } \\
\text { Psillaki and Daskalakis (2009). }\end{array}$ \\
\hline Profitability & $\begin{array}{l}\text { Earnings before interest and taxes } \\
\text { divided by total assets }\end{array}$ & $\begin{array}{l}\text { Salawu (2007), } \\
\text { Velnampy and Niresh (2012). }\end{array}$ \\
\hline Non-debt tax shields & $\begin{array}{l}\text { Depreciation and amortization } \\
\text { expenses divided by total assets }\end{array}$ & $\begin{array}{l}\text { Rajagopal (2011), } \\
\text { Moradi and Paulet (2019). }\end{array}$ \\
\hline Liquidity & $\begin{array}{l}\text { Current assets divided by current } \\
\text { liabilities }\end{array}$ & Deesomsak et al. (2009). \\
\hline Dependent Variables & Formulation & Empirical Evidence \\
\hline Short-term debt & $\begin{array}{l}\text { Short-term debt divided by total } \\
\text { assets }\end{array}$ & \multirow{2}{*}{$\begin{array}{l}\text { Booth et al. (2001), } \\
\text { Titman and Wessels (1988), } \\
\text { Feidakis and Rovolis (2007). } \\
\text { Rajan and Zingales (1995), } \\
\text { Booth et al. (2001). } \\
\text { Moradi and Paulet (2019), }\end{array}$} \\
\hline Long-term debt & $\begin{array}{l}\text { Long-term debt divided by total } \\
\text { assets }\end{array}$ & \\
\hline Total debt & Total debt divided by total assets & $\begin{array}{l}\text { Fama and French (2002), } \\
\text { Baker and Wurgler (2002). }\end{array}$ \\
\hline Net equity & $\begin{array}{l}\text { Shareholder equity divided by } \\
\text { total assets }\end{array}$ & Moradi and Paulet (2019). \\
\hline
\end{tabular}

\section{Results}

\subsection{Descriptive Statistics}

The descriptive statistics in Table 2 provide an overview of the distribution of the selected variables over the study period. The mean value of long-term debt (25.2 percent) is more than three times the mean value of short-term debt ( 8.8 percent). This debt structure is consistent with Akhtar's (2017) findings that multinationals operating under common law and the imputation tax system acquire significantly less short-term debt and significantly more long-term leverage, as well as long-term debt, which is more often used by multinational firms in the UK and USA. In line with Fan et al. (2012), developing countries heavily rely on short-term debt rather than long-term debt. Net equity was (46.2 percent), indicating that multinational firms have a significant proportion of equity in their capital structures. The lower average total debt implies that globalization impedes multinational firms' ability to diversify their businesses internationally, as it is quite plausible that multinational firms have a higher agency cost of debt financing than domestic firms. The tangibility of the selected multinational companies averaged 73.2 percent, which is relatively high given the asset-driven nature of the sector, indicating that less than (73 percent) of the total assets of the selected multinational companies are tangible. On the other hand, profitability averaged (4.5 percent), which is relatively low given the capital-intensive nature of the sector. The average effective tax rate was (2.8 percent), ranging from (-3.14) to (11.06), indicating a wide range of effective tax rates due to different income tax provisions, foreign tax credits and carry-forward losses of the companies. Firm size and liquidity variables had a large standard deviation of (2.334) and (2.336), respectively, indicating a high degree of data dispersion around their mean.

The correlation matrix between dependent and independent variables in Table 3 demonstrates that both short- and long-term debts are positively correlated with total debt. Short-term and long-term correlations, on the other hand, are inverse. Additionally, tangibility is positively correlated with all leverage measures, except short-term debt, indicating that tangibility could be used as a proxy for collateral when raising long-term 
debt. ETR is negatively correlated with all measures of leverage due to the fact that the external leverage of multinational firms is less susceptible to changes in tax advantages, and these firms adjust their external leverage more quickly than domestic firms. It is also evident that the majority of firm-level variables are negatively correlated with short-term debt. We test the variance inflation factor (VIF) to verify the correlation problem that results in skewed empirical results. Table 4 summarizes the VIF values for independent variables to quantify the possibility of multicollinearity. The maximum VIF is 2.48 , significantly less than the commonly used cut-off value of 10 for regression analysis. Moreover, we determined a mean VIF of less than 2. As a result, no evidence of multicollinearity or bias exists between independent variables to support the significance of our findings.

Table 2. Descriptive statistics for the sample.

\begin{tabular}{cccccc}
\hline Variable & Obs & Mean & Std Dev & Min & Max \\
\hline STD & 432 & 0.088 & 0.067 & 0 & 0.43 \\
LTD & 432 & 0.252 & 0.182 & 0 & 1.36 \\
TD & 432 & 0.340 & 0.191 & 0 & 1.52 \\
NE & 432 & 0.462 & 0.190 & 0.1 & 0.96 \\
ETR & 432 & 0.280 & 0.775 & 9.23 & 11.06 \\
Fsize & 432 & 15.70 & 2.334 & 0.06 & 19.83 \\
Tang & 432 & 0.732 & 0.172 & -1.07 & 0.98 \\
Risk & 432 & 0.040 & 0.092 & 0 & 1.27 \\
Prof & 432 & 0.045 & 0.131 & 0.14 & 0.75 \\
NDTS & 432 & 0.060 & 2.336 & 1.15 \\
Liq & 432 & 2.043 & 0.088 & 21.61
\end{tabular}

Note: The table presents the descriptive statistics. The variables of the study are defined in Table 1.

Table 3. Matrix of correlations.

\begin{tabular}{|c|c|c|c|c|c|c|c|c|c|c|}
\hline Variables & (1) & (2) & (3) & (4) & (5) & (6) & (7) & (8) & (9) & (10) \\
\hline STD & 1.000 & & & & & & & & & \\
\hline LTD & -0.051 & 1.000 & & & & & & & & \\
\hline $\mathrm{TD}$ & 0.301 & 0.937 & 1.000 & & & & & & & \\
\hline ETR & -0.085 & -0.091 & -0.117 & 1.000 & & & & & & \\
\hline Fsize & -0.039 & 0.158 & 0.137 & -0.060 & 1.000 & & & & & \\
\hline Tang & -0.382 & 0.415 & 0.263 & -0.088 & 0.302 & 1.000 & & & & \\
\hline Risk & -0.016 & -0.128 & -0.129 & 0.030 & -0.274 & -0.140 & 1.000 & & & \\
\hline Prof & 0.012 & 0.227 & 0.220 & 0.042 & 0.294 & -0.028 & -0.351 & 1.000 & & \\
\hline NDTS & 0.028 & -0.068 & -0.057 & -0.022 & -0.144 & -0.054 & 0.571 & -0.668 & 1.000 & \\
\hline Liq & -0.238 & -0.314 & -0.383 & 0.111 & -0.377 & -0.356 & 0.433 & -0.113 & 0.160 & 1.000 \\
\hline
\end{tabular}

Note: The table reports the correlation analysis of the dependent and independent variables. Abbreviations are: $\mathrm{STD}=$ Short-term debt; $\mathrm{LTD}=$ Long-term debt $\mathrm{TD}=$ Total debt $;$ ETR $=$ Effective tax rate; Fsize $=$ Firm size; Tang $=$ Tangibility $;$ Risk = Risk; Prof = Profitability; NDTS = Non-debt tax shields; Liq = Liquidity.

Table 4. Variance inflation factor (VIF) for the sample.

\begin{tabular}{ccc}
\hline & VIF & 1/VIF \\
\hline NDTS & 2.481 & 0.403 \\
Prof & 2.042 & 0.49 \\
Risk & 1.841 & 0.543 \\
Liq & 1.486 & 0.673 \\
Fsize & 1.377 & 0.726 \\
Tang & 1.227 & 0.815 \\
ETR & 1.019 & 0.982 \\
Mean VIF & 1.639 & -
\end{tabular}

Note: The table presents variance inflation factor (VIF) of independent variables to test multicollinearity. The variables are defined in Table 1. 


\subsection{Empirical Results}

The Hausman test results in Table 5 indicate that the fixed-effect model is more appropriate for explaining the relationship between the explanatory and dependent variables. Thus, we intend to omit the results of random-effect model and discuss the results obtained through OLS and fixed-effect models. Table 6 presents the main empirical results using three regression models of OLS, fixed-effect and random-effect models to statistically test the relationship and level of significance between explanatory variables that are effective tax rates and firm-level variables, such as firm size, tangibility, risk, profitability, net debt tax shields (NDTS) and liquidity, on different measures of capital structure. According to Table 6 , while the effective tax rate has a negative impact on leverage, it is found to be insignificant in determining the capital structure of multinational firms in the energy sector, as the fixed-effect model indicates. The OLS, on the other hand, emphasizes the importance of a negative relationship between the effective tax rate, short-term debt and total debt. The significant reason for this negative relationship is that multinationals are less likely to obtain short- and long-term debt due to reduced tax benefits and a significant decrease in the equity financing cost for the firms, in line with the findings of Macnamara (2019). Apparently, from our descriptive analysis, net equity exceeded total debt, on average. Another possible explanation is that multinational firms face a greater degree of variability in their effective tax rates due to their exposure to deferred tax liabilities, statutory tax rates and the establishment of valuation allowances on foreign tax credits, resulting in a higher effective tax rate.

Table 5. Hausman test specification.

\begin{tabular}{cccc}
\hline & Model 1 & Model 2 & Model 3 \\
& STD & LTD & TD \\
\hline $\mathrm{Chi}^{2}(7)$ & 28.36 & 22.15 & 26.48 \\
$\mathrm{Prob}>\mathrm{chi}^{2}$ & 0.0002 & 0.0009 & 0.0004 \\
\hline
\end{tabular}

Table 6. Regression estimates for the balanced panel dataset.

\begin{tabular}{|c|c|c|c|c|c|c|c|c|c|}
\hline \multirow{2}{*}{ Variables } & \multicolumn{3}{|c|}{ STD } & \multicolumn{3}{|c|}{ LTD } & \multicolumn{3}{|c|}{ TD } \\
\hline & OLS & FEM & REM & OLS & FEM & REM & OLS & FEM & REM \\
\hline \multirow[t]{2}{*}{ ETR } & $-0.007^{* *}$ & -0.003 & -0.003 & -0.012 & -0.001 & -0.002 & $-0.020 *$ & -0.004 & -0.005 \\
\hline & $(0.00)$ & $(0.00)$ & $(0.00)$ & $(0.01)$ & $(0.01)$ & $(0.01)$ & $(0.01)$ & $(0.01)$ & $(0.01)$ \\
\hline \multirow[t]{2}{*}{ Fsize } & -0.001 & 0.009 & 0 & $-0.010^{* * *}$ & -0.008 & 0.001 & $-0.012^{* * *}$ & 0.001 & 0.002 \\
\hline & $(0.00)$ & $(0.01)$ & $(0.00)$ & $(0.00)$ & $(0.02)$ & $(0.01)$ & $(0.00)$ & $(0.02)$ & $(0.01)$ \\
\hline \multirow[t]{2}{*}{ Tang } & $-0.208^{* * *}$ & $-0.150^{* * *}$ & $-0.163^{* * *}$ & $0.427^{* * *}$ & $0.214^{* * *}$ & $0.252 * * *$ & $0.220 * * *$ & 0.071 & 0.098 \\
\hline & $(0.02)$ & $(0.03)$ & $(0.02)$ & $(0.05)$ & $(0.07)$ & $(0.06)$ & $(0.05)$ & $(0.08)$ & $(0.07)$ \\
\hline \multirow[t]{2}{*}{ Risk } & $0.075^{*}$ & $0.083^{* * *}$ & $0.080^{* * *}$ & -0.036 & $0.178^{* * *}$ & $0.163 * *$ & 0.037 & $0.256^{* * *}$ & $0.240^{* * *}$ \\
\hline & $(0.04)$ & $(0.03)$ & $(0.03)$ & $(0.11)$ & $(0.06)$ & $(0.07)$ & $(0.12)$ & $(0.07)$ & $(0.07)$ \\
\hline \multirow[t]{2}{*}{ Prof } & -0.001 & -0.028 & -0.026 & $0.589^{* * *}$ & $0.406^{* * *}$ & $0.418^{* * *}$ & $0.588^{* * *}$ & $0.380^{* * *}$ & $0.392 * * *$ \\
\hline & $(0.03)$ & $(0.03)$ & $(0.03)$ & $(0.08)$ & $(0.06)$ & $(0.06)$ & (0.09) & $(0.07)$ & $(0.07)$ \\
\hline \multirow[t]{2}{*}{ NDTS } & 0.007 & $-0.067 *$ & $-0.064 *$ & $0.532 * * *$ & $0.455^{* * *}$ & $0.453^{* * *}$ & $0.537 * * *$ & $0.390 * * *$ & $0.390 * * *$ \\
\hline & $(0.05)$ & $(0.04)$ & $(0.04)$ & $(0.13)$ & $(0.10)$ & $(0.10)$ & $(0.14)$ & $(0.11)$ & $(0.10)$ \\
\hline \multirow[t]{2}{*}{ Liq } & $-0.014^{* * *}$ & $-0.014^{* * *}$ & $-0.013^{* * *}$ & $-0.016^{* * *}$ & 0.003 & 0.000 & $-0.029 * * *$ & $-0.011^{* *}$ & $-0.014^{* * *}$ \\
\hline & $(0.00)$ & $(0.00)$ & $(0.00)$ & $(0.00)$ & $(0.00)$ & $(0.00)$ & $(0.00)$ & $(0.01)$ & $(0.00)$ \\
\hline \multirow[t]{2}{*}{ Constant } & $0.282 * * *$ & 0.08 & $0.232 * * *$ & 0.082 & 0.155 & 0.001 & $0.365^{* * *}$ & 0.24 & 0.224 * \\
\hline & $(0.02)$ & $(0.09)$ & $(0.04)$ & $(0.06)$ & $(0.23)$ & $(0.12)$ & $(0.07)$ & $(0.25)$ & $(0.13)$ \\
\hline Observations & 432 & 432 & 432 & 432 & 432 & 432 & 432 & 432 & 432 \\
\hline R-squared & 0.325 & 0.161 & 0.305 & 0.294 & 0.156 & 0.200 & 0.252 & 0.161 & 0.188 \\
\hline Number of coid & 48 & 48 & 48 & 48 & 48 & 48 & 48 & 48 & 48 \\
\hline
\end{tabular}

Note: The table presents regression coefficients. The estimation method and the dependent variables are reported at the top of each column. Table 1 explains the definition of variables. Standard error in parentheses. ${ }^{* * *} p<0.01$, ** $p<0.05, * p<0.1$.

The fixed-effect results indicated that the variable firm size was insignificant, but the OLS regression results indicated a significant negative relationship between long-term debt and total debt, implying that multinationals rely less on debt financing despite their 
large size and easy access to financial markets. It could be that multinational companies prefer equity financing due to their good reputation, as large firms are less informationally opaque and disclose more information to investors. Thus, the possibility of undervaluation of new equity issuance is eliminated, and leverage is reduced, consistent with research by Rajan and Zingales (1995). Moreover, multinationals accumulate a large amount of retained earnings and are more likely to use internally generated funds to finance their operations to avoid debt-related agency costs under the pecking order theory. The highly significant positive relationship between tangibility and long-term debt reveals that the collateral aspect of tangible assets is central to capital structure determination of multinationals in the energy sector. However, the tangibility mechanism and leverage are not the same across the short-term and long-term debt. Tangibility is negatively associated with the short-term debt ratio, since the tangible nature of fixed assets makes them unsuitable for securing a short-term cash finance facility. In the case of total debt, OLS demonstrates a significant impact of tangibility. These findings are consistent with previous research and with trade-off theory, which suggests that financial markets lend debt to firms with a high proportion of fixed assets due to their high collateral value and that such assets are used by firms to secure long-term debt and are relatively easy to repossess in the event of bankruptcy (Booth et al. 2001; Chen 2004; Frank and Goyal 2009).

The variable risk is found to be strongly positive and statistically significant when compared to all three leverage measures. This is contrary to our expected hypothesis, as earnings volatility may increase the risk of default on debt payments. The rationale for this finding is that multinational firms, owing to their ability to mitigate business risks through international diversification of their portfolios, international debt sourcing and transfer pricing, are willing to take on greater risks in exchange for higher returns via increased debt financing. Additionally, the increased agency cost of debt encourages riskier firms to borrow more to shift the risk burden to lenders, implying a direct relationship between risk and leverage, consistent with Fama and French (2002). Concerning profitability and the net debt tax shield, a positive and highly significant relationship between long-term debt and total debt is reported. In the case of profitability and short-term debt, the relationship is negative and insignificant, while the relationship between net debt tax shield and short-term debt is significantly negative. A strong positive relationship between multinational firms' profitability and long-term and total debt supports the relevance of the trade-off theory over the pecking order theory, implying that highly profitable firms are more receptive to higher tax burdens and lower bankruptcy costs, which ultimately provides them with an adamant reason to use more leverage, as they have a greater capacity to tolerate debt and its timely servicing, in comparison to low profitable firms, in line with the findings of (Frank and Goyal 2003; Antoniou et al. 2008; Wu and Yue 2009).

The findings on the non-debt tax shield are unexpectedly contrary to our expectations and findings of previous studies, such as Bennett and Donnelly (1993) and Kim et al. (2006). However, they aligned with the results of Bradley et al. (1984) and Mukherjee and Mahakud (2010), who reported that non-debt tax shields are significantly positively associated with long-term and total debt. A notable reason is that multinational firms in the energy sector invest heavily in fixed assets and are heavily involved in oil and gas exploration, which results in a high depreciation rate, enabling firms to secure a higher level of long-term debt rather than shielding income solely through interest deductibility. Another plausible explanation is that large companies have a high pretax income, which enables them to take advantage of not only tax shelters but also non-debt shelters, such as amortization, depreciation and research and development expenditures. On the other hand, liquidity has a significant negative relationship with short-term and total debt but is insignificant with long-term debt. Multinational firms appear to maintain a strong liquidity position and, rather than obtaining short-term financing from an external source, they prefer to finance their operations through their liquid assets, accumulated cash and internal sources of funds, which is consistent with the pecking order theory and the findings of (Eriotis et al. 2007; Deesomsak et al. 2009). 


\subsection{Robustness Test}

In this section, we examine the empirical results' robustness to an alternative capital structure measure based on net equity as the dependent variable. The explanatory variables remained constant, and Table 7 summarizes the findings. The reason for using the net equity measure of capital structure is to ensure the accuracy of the results, as only the debt explicitly measures present debt behavior while omitting to report on the company's equity variations. By way of illustration, if leverage is defined solely in terms of total debt over total assets, we assume that debt and equity are increased by $50 \%$, while the value of total assets remains unchanged. Leverage will be increased by $50 \%$, but we will not report the same increase and proportional equity fluctuations. Thus, we employ the net equity metric, a critical component of capital structure, defined as the difference between the book value of total assets and liabilities divided by the book value of total assets. The new measure confirms our earlier findings by indicating a significant positive relationship between effective tax rate and net equity under OLS and positive insignificance under fixed effect. The reason for a positive relationship supports the dynamic trade-off theory, meaning that multinational firms are less responsive to tax cuts and only increase long-term leverage in the case of tax rate increases, particularly in a low-tax statutory tax jurisdiction. In contrast, firm-level characteristics, such as firm size, risk, profitability and non-debt tax shields are significantly negative concerning net equity, consistent with the above strand of our empirical findings. We find no correlation between tangibility and net equity, indicating that multinationals, contrary to the pecking order theory, rely on high tangible assets to pursue debt financing and avoid internal sources of funds. In contrast to the findings for liquidity with all three debt measures of capital structure, liquidity has a strong, significant and positive relationship with net equity.

Table 7. Regression results for the dependent variable net equity.

\begin{tabular}{cccc}
\hline \multirow{2}{*}{ Variables } & & NE & \\
\cline { 2 - 4 } & OLS & FEM & REM \\
\hline ETR & $0.019^{*}$ & 0.002 & 0.004 \\
Fsize & $(0.01)$ & $(0.01)$ & $(0.01)$ \\
& -0.004 & -0.021 & $-0.016^{* *}$ \\
Tang & $(0.00)$ & $(0.02)$ & $(0.01)$ \\
Risk & -0.039 & 0.077 & 0.046 \\
& $(0.05)$ & $(0.08)$ & $(0.07)$ \\
Prof & -0.11 & $-0.298^{* * *}$ & $-0.274^{* * *}$ \\
NDTS & $(0.11)$ & $(0.08)$ & $(0.08)$ \\
& $-0.677^{* * *}$ & $-0.381^{* * *}$ & $-0.413^{* * *}$ \\
Liq & $(0.08)$ & $(0.07)$ & $(0.07)$ \\
& $-0.585^{* * *}$ & $-0.379^{* * * *}$ & $-0.392^{* * *}$ \\
Constant & $(0.13)$ & $(0.11)$ & $(0.11)$ \\
& $0.047^{* * *}$ & $0.031^{* * *}$ & $0.035^{* * *}$ \\
Observations & $(0.00)$ & $(0.01)$ & $(0.00)$ \\
R-squared & $0.522^{* * *}$ & $0.714^{* * *}$ & $0.664^{* * *}$ \\
Number of coid & $(0.07)$ & $(0.27)$ & $(0.12)$ \\
\hline The & $432^{* *}$ & 432 & 432 \\
& 0.428 & 0.231 & 0.389 \\
\hline
\end{tabular}

Note: The table presents regression coefficients. The estimation method and the dependent variable as a new measure of capital structure is reported at the top of each column to check robustness. The definition of variables is reported in Table 1. Standard error in parentheses. ${ }^{* *} p<0.01,{ }^{* *} p<0.05,{ }^{*} p<0.1$.

\section{Conclusions}

This study employs OLS, fixed- and random-effect multiple regression models to investigate the relationship between effective tax rate and leverage, as well as the effects of firm-specific factors on various measures of capital structure, a topic of ongoing debate in 
the field of corporate finance. Recent studies have concentrated on domestic non-financial firms across sectors in emerging economies, with little emphasis on multinational firms in a single industry, as they face more business opportunities and economic forces operating in an international environment than their domestic counterparts. This study bridges the gap by examining the effect of multinational firms' effective tax rates and firm-level characteristics on the capital structure using a balanced panel dataset of multinational firms listed on the London and New York stock exchanges and operating in the energy sector, with headquarters in the UK and US. The results indicate that tangibility, risk, profitability and non-debt tax shields are significantly positively related to long-term and total debt measures of leverage but have a significantly negative relation of tangibility, non-debt tax shields and liquidity with short-term debt, and a positive significance between risk and short-term debt is observed. Furthermore, we showed that effective tax rate and firm size are insignificantly negatively associated with leverage, as per fixed-effect results. However, OLS results indicate that the effective tax rate is significantly negatively related to short-term and total debt, and firm size is negatively related to long-term and total debt. Moreover, liquidity is negatively associated with long-term debt and total debt. Thus, this study provided mixed support for the prevailing theories of capital structure and evidence that multinationals are unequivocally responsive to the capital structure determinants.

This paper has some policy implications. First, the outcome of our work is an addition to the existing body of literature, providing important insights that are very useful for companies in the energy sector to achieve financial growth by attaining optimal capital structure. In addition, it would assist practitioners in strengthening taxation systems and building an effective taxation policy, considering the role of deferred tax liabilities, statutory tax rates and the establishment of valuation allowances on foreign tax credits, which are creating greater degree of variability in the effective tax rates of multinational firms in the UK and US, resulting in a higher effective tax rate. Second, it provides a significant contribution in the corporate environment to develop valuable capital structure strategy and better identification of capital structure dynamics of multinationals in the energy sector of developed economies. However, this study has some limitations. In particular, the study does not perform each country's regression analysis due to the smaller sample size of listed multinationals in each country after specifying the criteria on the Orbis database. The sample of both countries, therefore, pooled together to examine the factor affecting the capital structure. Another limitation of this study is the lack of availability of the unconsolidated financial data of the multinationals. Thus, we have to rely on the consolidated financial information of the companies. Future research could incorporate sectorial analysis of different macro-economic factors and firm-specific characteristics to examine the distinctive impact of the multinationals' capital structure in other manufacturing sectors. Examining the influence of double tax treaties on the capital structure of multinational firms, in terms of direct and indirect foreign tax credits, is an area of prospective research. Further, the comparison between multinational and domestic firms with no foreign subsidiary in the same industry could be investigated to examine the effects of distinctive classifications of capital structure determinants.

Author Contributions: Conceptualization, S.A. and A.R.; methodology, S.A. and M.F.; software, M.F.; validation, S.A., A.R. and M.F.; formal analysis, M.F.; investigation, S.A. and M.F.; resources, S.A.; data curation, S.A. and M.F.; writing-original draft preparation, S.A. and A.R.; writing-review and editing, S.A. and A.R.; visualization, S.A.; supervision, A.R. All authors have read and agreed to the published version of the manuscript.

Funding: This research received no external funding.

Institutional Review Board Statement: Not applicable.

Informed Consent Statement: Not applicable.

Data Availability Statement: The Orbis Bureau van dijk database is used for the collection of companies financial data. 
Conflicts of Interest: The authors declare no conflict of interest.

\section{References}

Acaravci, Songul Kakilli. 2015. The determinants of capital structure: Evidence from the Turkish manufacturing sector. International Journal of Economics and Financial Issues 5: 158.

Akhtar, Shumi. 2017. Capital structure of multinational and domestic corporations-A cross-country comparison. Accounting and Finance 57: 319-49. [CrossRef]

Ali, Syed Atif, Shahid A. Zia, and Amir Razi. 2012. Impact of Capital Structure on the Profitability of Petroleum Sector in Pakistan. Global Journal of Management and Business Research 12: 22.

Allen, Franklin, Rajesh Chakrabarti, Jun Qian, and Meijun Qian. 2006. Financing firms in India. Washington, DC: The World Bank.

Al-Najjar, Basil, and Peter Taylor. 2008. The relationship between capital structure and ownership structure, New evidence from Jordanian panel data. Managerial Finance 34: 919-33. [CrossRef]

Antoniou, Antonios, Yilmaz Guney, and Krishna Paudyal. 2008. The determinants of capital structure: Capital market-oriented versus bank-oriented institutions. Journal of Financial and Quantitative Analysis 43: 59-92. [CrossRef]

Arena, Matteo P, and Andrew H. Roper. 2010. The effect of taxes on multinational debt location. Jouranl of Corporate Finance 16: 637-54. [CrossRef]

Auerbach, Alan J., Michael P. Devereux, Michael Keen, and John Vella. 2017. Destination-Based Cash Flow Taxation. Working Paper17/01. Oxford: Oxford University Centre for Business Taxation.

Baker, H. Kent, and Leigh A. Riddick, eds. 2013. International Finance: A Survey. Oxford: Oxford University Press.

Baker, Malcolm, and Jeffrey Wurgler. 2002. Market timing and capital structure. The Journal of Finance 57: 1-32. [CrossRef]

Barclay, Michael, Shane M. Heitzman, and Clifford W. Smith. 2013. Debt and taxes: Evidence from the real estate industry. Journal of Corporate Finance 20: 74-93. [CrossRef]

Bartholdy, Jan, and Cesário Mateus. 2011. Debt and taxes for private firms. International Review of Financial Analysis 20: 177-89. [CrossRef]

Baum, Christopher F., Andreas Stephan, and Oleksandr Talavera. 2009. The effects of uncertainty on the leverage of nonfinancial firms. Economic Inquiry 47: 216-25. [CrossRef]

Bennett, M. A. D. R., and Ray Donnelly. 1993. The determinants of capital structure: Some UK evidence. The British Accounting Review 25: 43-59. [CrossRef]

Bhaduri, Saumitra N. 2002. Determinants of capital structure choice: A study of the Indian corporate sector. Applied Financial Economics 12: 655-65. [CrossRef]

Booth, Laurence, Varouj Aivazian, Asli Demirguc-Kunt, and Vojislav Maksimovic. 2001. Capital structures in developing countries. Journal of Finance 56: 87-130. [CrossRef]

Bradley, Michael, Gregg A. Jarrell, and E. Han Kim. 1984. On the existence of an optimal capital structure: Theory and evidence. The Journal of Finance 39: 857-78. [CrossRef]

Brogan, Andy. 2014. Funding Challenges in the Oil and Gas Sector. Available online: https:/ /www.ey.com/Publication/vwLUAssets/ EY-Funding-challenges-in-the-oil-and-gas-sector/\$FILE/EY-Funding-challenges-in-the-oil-and-gas-sector.pdf (accessed on 21 September 2021).

Cariola, Alfio, Francesco Fasano, Maurizio La Rocca, and Ekaterina Skatova. 2020. Environmental sustainability policiesand the value of debt in EU SMEs: Empirical evidence from the energy sector. Journal of Cleaner Production 275: 123133. [CrossRef]

Castanias, Richard. 1983. Bankruptcy risk and optimal capital structure. The Journal of Finance 38: 1617-35. [CrossRef]

Castillo, Augusto, Jorge Niño, and Salvador Zurita. 2017. Debt Tax Shields Around the OECD World. Emerging Markets Finance and Trade 53: 26-43. [CrossRef]

Céspedes, Jacelly, Maximiliano González, and Carlos A. Molina. 2010. Ownership and capital structure in Latin America. Journal of Business Research 63: 248-54. [CrossRef]

Chaklader, Barnali, and Deepak Chawla. 2016. A study of determinants of capital structure through panel data analysis of firms listed in NSE CNX 500. Vision 20: 267-77. [CrossRef]

Chakraborty, Indrani. 2010. Capital structure in an emerging stock market: The case of India. Research in International Business and Finance 24: 295-314. [CrossRef]

Chen, Jean. J. 2004. Determinants of capital structure of Chinese-listed companies. Journal of Business Research 57: 1341-51. [CrossRef]

Chung, Kee. H. 1993. Asset characteristics and corporate debt policy: An empirical test. Journal of Business Finance E Accounting 20: 83-98.

Clemente-Almendros, José A., and Francisco Sogorb-Mira. 2017. How much do the tax benefits of debt add to firm value? Evidence from Spanish listed firms. Revista de Economía Aplicada 25: 105-29.

Colombo, Jéfferson A., and João F. Caldeira. 2018. The role of taxes and the interdependence among corporate financial policies: Evidence from a natural experiment. Journal of Corporate Finance 50: 402-23. [CrossRef]

Da Fonseca, Peter, Michele Nascimento Jucá, and Wilson Toshiro Nakamura. 2020. Debt tax benefits in a high tax emerging market: Evidence from Brazil. International Journal of Economics and Business Administration 8: 35-52. [CrossRef]

Dallari, Pietro, Mr Nicolas End, Fedor Miryugin, Alexander F. Tieman, and Mr Seyed Reza Yousefi. 2020. Pouring oil on fire: Interest deductibility and corporate debt. International Tax and Public Finance 27: 1520-56. [CrossRef] 
Damodaran, Aswath. 2012. Investment Valuation: Tools and Techniques for Determining the Value of Any Asset. Hoboken: John Wiley \& Sons, vol. 666.

Dayanandan, Ajit, and Han Donker. 2011. Oil prices and accounting profits of oil and gas companies. International Review of Financial Analysis 20: 252-57. [CrossRef]

De Jong, Abe, Rezaul Kabir, and Thuy Thu Nguyen. 2008. Capital structure around the world: The roles of firm-and country-specific determinants. Journal of Banking and Finance 32: 1954-69. [CrossRef]

Deesomsak, Rataporn, Krishna Paudyal, and Gioia Pescetto. 2009. The determinants of debt maturity structure: Evidence from the Asia Pacific region. Journal of Multinational Financial Management 19: 26-42. [CrossRef]

Delcoure, Natalya. 2007. The determinants of capital structure in transitional economies. International Review of Economics and Finance 16: 400-15. [CrossRef]

Demirgüç-Kunt, Asli, and Vojislav Maksimovic. 1996. Stock market development and financing choices of firms. The World Bank Economic Review 10: 341-69. [CrossRef]

Desai, Mihir A., C. Fritz Foley, and James R. Hines Jr. 2004. A multinational perspective on capital structure choice and internal capital markets. Journal of Finance 59: 2451-87. [CrossRef]

Devereux, Michael P., Giorgia Maffini, and Jing Xing. 2018. Corporate tax incentives and capital structure: New evidence from UK firm-level tax returns. Journal of Banking and Finance 88: 250-66. [CrossRef]

Drobetz, Wolfgang, and Roger Fix. 2003. What are the determinants of capital structure? Some evidence from Switzerland. University of Basel. WWZ/Department of Finance Working Paper 4: 14-10.

Eriotis, Nikolaos, Dimitrios Vasiliou, and Zoe Ventoura-Neokosmidi. 2007. How firm characteristics affect capital structure: An empirical study. Managerial Finance 33: 321-31. [CrossRef]

EY. 2019. Global Oil and Tax Guide. Available online: https://www.ey.com/en_gl/tax-guides/global-oil-and-gas-tax-guide-2019 (accessed on 28 October 2021).

Faccio, Mara, and Jin Xu. 2015. Taxes and capital structure. Journal of Financial and Quantitative Analysis 50: 277-300. [CrossRef]

Fama, Eugene F., and Kenneth R. French. 2002. Testing trade-off and pecking order predictions about dividends and debt. The Review of Financial Studies 15: 1-33. [CrossRef]

Fan, Joseph PH, Sheridan Titman, and Garry Twite. 2012. An international comparison of capital structure and debt maturity choices. Journal of Financial and Quantitative Analysis 47: 23-56. [CrossRef]

Faulkender, Michael, and Jason M. Smith. 2016. Taxes and leverage at multinational corporations. Journal of Financial Economics 122 : 1-20. [CrossRef]

Feidakis, Andreas, and Antonios Rovolis. 2007. Capital structure choice in European Union: Evidence from the construction industry. Applied Financial Economics 17: 989-1002. [CrossRef]

Frank, Murray Z., and Vidhan K. Goyal. 2003. Testing the pecking order theory of capital structure. Journal of Financial Economics 67: 217-48. [CrossRef]

Frank, Murray Z., and Vidhan K. Goyal. 2009. Capital structure decisions: Which factors are reliably important? Financial Management 38: 1-37. [CrossRef]

Giannetti, Mariassunta. 2003. Do better institutions mitigate agency problems? Evidence from corporate finance choices. Journal of Financial and Quantitative Analysis 38: 185-212. [CrossRef]

Gill, Amarjit, Nahum Biger, Chenping Pai, and Smita Bhutani. 2009. The determinants of capital structure in the service industry: Evidence from United States. The Open Business Journal 2: 1. [CrossRef]

Gordon, Roger, and Young Lee. 2007. Interest rates, taxes and corporate financial policies. National Tax Journal 60: 65-84. [CrossRef]

Graham, John R., and Campbell R. Harvey. 2001. The theory and practice of corporate finance: Evidence from the field. Journal of Financial Economics 60: 187-243. [CrossRef]

Graham, John R., Michael L. Lemmon, and James S. Schallheim. 1998. Debt, leases, taxes, and the endogeneity of corporate tax status. Journal of Finance 53: 131-62. [CrossRef]

Handoo, Anshu, and Kapil Sharma. 2014. A study on determinants of capital structure in India. IIMB Management Review 26: 170-82. [CrossRef]

Hanousek, Jan, and Anastasiya Shamshur. 2011. A stubborn persistent: Is the stability of leverage ratios determined by the stability of the economy. Journal of Corporate Finance 17: 1360-76. [CrossRef]

Harris, Milton, and Artur Raviv. 1991. The theory of capital structure. Journal of Finance 46: 297-355. [CrossRef]

Heider, Florian, and Alexander Ljungqvist. 2015. As certain as debt and taxes: Estimating the tax sensitivity of leverage from state tax changes. Journal of Financial Economics 118: 684-712. [CrossRef]

Homaifar, Ghassem, Joachim Zietz, and Omar Benkato. 1994. An empirical model of capital structure: Some new evidence. Journal of Business Finance \& Accounting 21: 1-14.

Huang, Rongbing, and Jay R. Ritter. 2009. Testing theories of capital structure and estimating the speed of adjustment. Journal of Financial and Quantitative Analysis 44: 237-71. [CrossRef]

Huizinga, Harry, Luc Laeven, and Gaetan Nicodeme. 2008. Capital structure and international debt shifting. Journal of Financial Economics 88: 80-118. [CrossRef]

Jaworski, Jacek, and Leszek Czerwonka. 2021. Determinants of enterprises' capital structure in energy industry: Evidence from European Union. Energies 14: 1871. [CrossRef] 
Jensen, Michael C., and William H. Meckling. 1976. Theory of the firm: Managerial behavior, agency costs and capital structure. Journal of Financial Economics 3: 305-60. [CrossRef]

Kale, Jayant R., Thomas H. Noe, and Gabriel G. Ramirez. 1991. The effect of business risk on corporate capital structure: Theory and evidence. The Journal of Finance 46: 1693-715. [CrossRef]

Karadeniz, Erdinc, Y. Serkan, and Omer Iskenderoglu. 2011. Firm size and capital structure decisions: Evidence from Turkish lodging companies. International Journal of Economics and Financial Issues 1: 1.

Kim, Hyesung, Almas Heshmati, and Dany Aoun. 2006. Dynamics of capital structure: The case of Korean listed manufacturing companies. Asian Economic Journal 20: 275-302. [CrossRef]

Kraus, Alan, and Robert H. Litzenberger. 1973. A State-Preference Model of Optimal Financial Leverage. Journal of Finance 28: 911-22. [CrossRef]

Kuntchev, Veselin, Rita Ramalho, Jorge Rodríguez-Meza, and Judy S. Yang. 2014. What Have We Learned from the Enterprise Surveys Regarding Access to Finance by SMEs? Group Policy Research Working Paper. Washington, DC: The World Bank.

La Porta, Rafael, Florencio Lopez-de-Silanes, Andrei Shleifer, and Robert W. Vishny. 1997. Legal determinants of external finance. The Journal of Finance 52: 1131-50. [CrossRef]

Lemmon, Michael L., Michael R. Roberts, and Jaime F. Zender. 2008. Back to the beginning: Persistence and the cross-section of corporate capital structure. The Journal of Finance 63: 1575-608. [CrossRef]

Longstaff, Francis A., and Ilya A. Strebulaev. 2014. Corporate Taxes and Capital Structure: A Long-Term Historical Perspective. No. w20372. Cambridge: National Bureau of Economic Research.

MacKay, Peter, and Gordon M. Phillips. 2005. How does industry affect firm financial structure? The Review of Financial Studies 18: 1433-66. [CrossRef]

Macnamara, Patrick. 2019. Taxes and financial frictions: Implications for corporate capital structure. Journal of Economic Dynamics and Control 101: 82-100. [CrossRef]

Masini, Andrea, and Emanuela Menichetti. 2012. The impact of behavioural factors in the renewable energy investment decision making process: Conceptual framework and empirical findings. Energy Policy 40: 28-38. [CrossRef]

Mc Namara, Andrea, Pierluigi Murro, and Sheila O'Donohoe. 2017. Countries lending infrastructure and capital structure determination: The case of European SMEs. Journal of Corporate Finance 43: 122-38. [CrossRef]

McClure, Kenneth G., Ronnie Clayton, and Richard A. Hofler. 1999. International capital structure differences among the G7 nations: A current empirical view. The European Journal of Finance 5: 141-64. [CrossRef]

McConnell, John J., and R. Richardson Pettit. 1984. Application of the modern theory of finance to small business firms. In Small Business Finance: Problems in Financing of Small Business. Edited by P. M. Horvitz and R. R. Pettit. Greenwich: JAI Press, vol. 42.

Miller, Merton H. 1977. Debt and taxes. Journal of Finance 32: 261-75.

Mills, Lillian F., and Kaye J. Newberry. 2004. Do foreign multinationals' tax incentives influence their U.S. income reporting and debt policy? National Tax Journal 57: 89-107. [CrossRef]

Modigliani, Franco, and Merton H. Miller. 1958. The cost of capital, corporation finance and the theory of investment. The American Economic Review 48: 261-97.

Modigliani, Franco, and Merton H. Miller. 1963. Corporate income taxes and the cost of capital: A correction. The American Economic Review 53: 433-43.

Moradi, Amir, and Elisabeth Paulet. 2019. The firm-specific determinants of capital structure-An empirical analysis of firms before and during the Euro Crisis. Research in International Business and Finance 47: 150-61. [CrossRef]

Mukherjee, Sulagna, and Jitendra Mahakud. 2010. Dynamic adjustment towards target capital structure: Evidence from Indian companies. Journal of Advances in Management Research 7: 250-66. [CrossRef]

Myers, Stewart. C. 1977. Determinants of corporate borrowing. Journal of Financial Economics 5: 147-75. [CrossRef]

Myers, Stewart C. 1984. The capital structure puzzle. Journal of Finance 39: 575-92. [CrossRef]

Myers, Stewart C. 2001. Capital structure. Journal of Economic Perspectives 15: 81-102. [CrossRef]

Myers, Stewart C., and Nicholas S. Majluf. 1984. Corporate financing and investment decisions when firms have information that investors do not have. Journal of Financial Economics 13: 187-221. [CrossRef]

OECD. 1997. Model Tax Convention on Income and on Capital. Paris: OECD.

Ozkan, Aydin. 1996. Corporate bankruptcies, liquidation costs and the role of banks. The Manchester School of Economic E Social Studies 64: 104-19.

Psillaki, Maria, and Nikolaos Daskalakis. 2009. Are the determinants of capital structure country or firm specific? Small Business Economics 33: 319-33. [CrossRef]

Rajagopal, Sanjay. 2011. The portability of capital structure theory: Do traditional models fit in an emerging economy? Journal of Finance and Accountancy 5: 1.

Rajan, Raghuram G., and Luigi Zingales. 1995. What do we know about capital structure? Some evidence from international data. The Journal of Finance 50: 1421-60. [CrossRef]

Ramli, Nur Ainna, Hengky Latan, and Grace T. Solovida. 2019. Determinants of capital structure and firm financial performance-A PLS-SEM approach: Evidence from Malaysia and Indonesia. The Quarterly Review of Economics and Finance 71: 148-60. [CrossRef]

Rashid, Abdul. 2013. Risks and financing decisions in the energy sector: An empirical investigation using firm-level data. Energy Policy 59: 792-99. [CrossRef] 
Ross, Stephen. 2007. Corporate Finance: Core Principles \& Applications. New York: McGraw-Hill.

Rünger, Rainer Niemann, and Magdalena Haring. 2019. Investor taxation, firm heterogeneity and capital structure choice. International Tax and Public Finance 26: 719-57. [CrossRef] [PubMed]

Salawu, Rafiu Oyesola. 2007. An empirical analysis of the capital structure of selected quoted companies in Nigeria. The International Journal of Applied Economics and Finance 1: 16-28.

Sheikh, Nadeem Ahmed, and Zongjun Wang. 2011. Determinants of capital structure: An empirical study of firms in manufacturing industry of Pakistan. Managerial Finance 37: 117-133. [CrossRef]

Terhaag, Joris. 2015. Determinants of Capital Structure: A Comparison Between Small and Large Firms. Mimeo. Available online: http:/ / arno.uvt.nl/ show.cgi?fid=142143 (accessed on 28 October 2021).

Thillairajan, A., and Monalisa Behera. 2016. Private equity investment in power generation projects: Evidence from India. International Journal of Energy Sector Management 10: 617-41. [CrossRef]

Titman, Sheridan, and Roberto Wessels. 1988. The determinants of capital structure choice. The Journal of Finance 43: 1-19. [CrossRef]

Toy, Norman, Arthur Stonehill, Lee Remmers, Richard Wright, and Theo Beekhuisen. 1974. A comparative international study of growth, profitability, and risk as determinants of corporate debt ratios in the manufacturing sector. Journal of Financial and Quantitative Analysis 9: 875-86. [CrossRef]

Truly, Richard H., and Michal C. Moore. 2016. Renewable Energy: Balancing Risk and Reward. Perspectives on Complex Global Challenges. In Education, Energy, Healthcare, Security and Resilience. Hoboken: Wiley, pp. 89-91.

Velnampy, T., and J. Aloy Niresh. 2012. The relationship between capital structure and profitability. Global Journal of Management and Business Research 12: 13.

Wenhong, Li, Wu Jiaqi, and Hu Tianran. 2015. The Effects of Corporate Income Tax on Corporate Capital Structure-Based on the Data of Listed Companies in China. International Journal of Economics and Finance 8: 166. [CrossRef]

$\mathrm{Wu}$, Liansheng, and Heng Yue. 2009. Corporate tax, capital structure, and the accessibility of bank loans: Evidence from China. Journal of Banking \& Finance 33: 30-38.

Zou, Hong, and Jason Zezhong Xiao. 2006. The financing behaviour of listed Chinese firms. The British Accounting Review 38: 239-58. [CrossRef] 